\title{
The synthesis and actions of steroids and prostaglandins during follicular maturation in the pig
}

\author{
L. Ainsworth*, B. K. Tsang $\dagger$, B. R. Downey $\ddagger$ and G. J. Marcus*
}

* Animal Research Centre, Agriculture Canada, Ottawa, Ontario, Canada KIA OC6; †Reproductive Biology Unit, Departments of Obstetrics and Gynecology and of Physiology, University of Ottawa and Loeb Institule of Medical Research, Otlawa Civic Hospital, Otlawa, Ontario, Canada KIY 4E9; and $\ddagger$ Department of Animal Science, Macdonald College of $M c$ Gill University,

Ste. Anne de Bellevue, Québec, Canada $\mathrm{H} 9 \mathrm{X} 1 \mathrm{CO}$

\begin{abstract}
Summary. Our understanding of the synthesis and production of follicular steroids and prostaglandins (PG) in the pig is based largely on in-vitro studies with granulosa and theca interna tissues obtained from Graafian follicles at various stages of maturation. As the follicle enlarges before the LH surge, granulosa cells exhibit a decrease in FSH receptors and are less responsive to FSH in terms of cAMP production. Concurrently, there is an increase in granulosa and thecal cell LH receptors associated with an increase in responsiveness to $\mathrm{LH}$ and an increase in steroid production. Both granulosa and thecal cells produce oestrogen and progesterone, the rates of production being dependent on the stage of maturation of the follicle and substrate availability. Thecal cells are the principal source of androgens and control oestrogen synthesis by providing aromatizable substrate. After exposure to $\mathrm{LH} / \mathrm{hCG}$ in vivo, both cell types lose the ability to produce oestrogen in vitro. These studies support the two-cell, twogonadotrophin hypothesis of ovarian steroidogenesis.

In vitro, granulosa and thecal cells exhibit an increased ability to produce PGE-2 and PGF-2 $\alpha$ after exposure to $\mathrm{LH} / \mathrm{hCG}$ in vivo. Follicular PG production appears to be regulated by arachidonic acid availability and $P G$ synthetase activity. In vivo, the follicular fluid concentrations of PGE-2 and PGF-2 $\alpha$ increase markedly at the time of ovulation. The increases in PG levels and ovulation can be blocked by indomethacin, an inhibitor of PG synthesis. These studies provide convincing evidence for an intrafollicular source of PGs and are consistent with the hypothesis that LH induces an increase in PG production that is essential for rupture of the follicle.

Steroids act on the follicle through autocrine and paracrine mechanisms to modulate follicular growth and differentiation and to regulate steroidogenesis. PG actions on the follicle appear to be exerted via effects on contractile elements of the theca externa, blood vessels and on collagenolytic and other proteolytic enzymes.
\end{abstract}

Keywords: steroids; prostaglandins; synthesis; ovary; follicles; pig

\section{Introduction}

In mammals, FSH initiates formation and maturation of the Graafian follicle, at the same time inducing increases in ovarian oestrogen synthesis. The resultant rise in circulating oestrogen triggers the preovulatory LH surge which then induces ovulation. This ovulatory response of the follicles consists of three basic components-alteration of steroidogenesis which converts the follicle from one secreting primarily oestrogen to one secreting progesterone, resumption of meiosis in the primary oocyte and rupture of the follicle followed by extrusion of the ovum enclosed in cumulus mass. 
Steroidogenesis during maturation of the Graafian follicle is a complex process involving the interaction of two follicular compartments, the membrana granulosa and the theca interna, co-ordinated by a sequence of actions of pituitary gonadotrophins and intragonadal regulators (Ireland, 1987). The granulosa and theca interna cells undergo differentiation characterized by the acquisition of various hormone receptors, changes in responsiveness to pituitary hormones and the development of and/or alterations in steroidogenic capabilities (Richards, 1980; Hsueh et al., 1984; Erickson et al., 1985). Prostaglandins also appear to play a fundamental role in at least some of the steps in the ovulatory process inasmuch as the inhibition of prostaglandin synthesis by indomethacin blocks ovulation in a number of species (Armstrong, 1981).

This review will focus on the synthesis and actions of steroids and prostaglandins during follicular maturation in the pig. When appropriate, reference will be made to studies in other species to provide a wider perspective and allow some generalizations and conclusions.

\section{Follicular steroidogenesis in the pig}

Pig ovarian tissue has been used extensively to study granulosa cell differentiation and the steroidogenic potential of granulosa and thecal tissues during follicular development. Many of the studies have made use of granulosa cells maintained in vitro in monolayer culture or incubated in suspension. Thecal tissue, however, with or without granulosa cell contamination, has usually been maintained in culture as explants or incubated as thecal fragments. Under such experimental conditions, a comparison of the steroidogenic abilities or hormonal responsiveness could not be made with assurance because observed differences may have been due merely to different states of tissue aggregation, affecting solute and gas exchange. Interpretation of observations has also been hindered by the fact that follicles are frequently obtained from abattoir material and the stage of development estimated from the size of the follicle (Channing \& Ledwitz-Rigby, 1975). Despite these limitations, such studies have provided much information on the control of follicular growth and maturation in the pig.

To overcome some of the problems cited above, methods have been developed to disperse granulosa and theca interna tissues enzymically and provide cell suspensions (Stoklosowa $e t a l$., 1978; Marcus et al., 1984). In our own work, we have used the prepubertal gilt treated with 750 i.u. PMSG and with 500 i.u. hCG $72 \mathrm{~h}$ later as a source of preovulatory follicles (Ainsworth $e t$ al., 1982). This treatment produces ovaries which contain a population of uniformly developing follicles which ovulate approximately $42 \mathrm{~h}$ after hCG treatment. Thus ovaries removed at laparotomy, will contain follicles at well-defined stages of preovulatory development. The chronology of follicular growth, oocyte maturation, changes in cumulus cell morphology and number of follicles which ovulate, correspond closely to those observed in the mature cyclic female (Ainsworth et al., 1982). It is therefore assumed that the physiological events induced by PMSG/hCG treatment of prepubertal gilts correspond closely to those which occur in spontaneously ovulating animals.

\section{Gonadotrophin and prolactin receptors during follicular maturation (Fig. 1)}

Several in-vitro studies have documented the relationship between follicle size (as an indicator of the stage of follicle development) and the appearance of FSH and LH receptors on granulosa and thecal cells, as well as the functional linkage of these receptors to the adenylate cyclase-cAMP system. FSH appeared to bind only to granulosa cells and the number of FSH receptors and FSH-sensitive adenylate cyclase activity of granulosa cells decreased as the follicle enlarged (Nakano et al., 1977; Lee, 1978; Lindsey \& Channing, 1979). In contrast, granulosa and thecal tissues from large follicles contained more LH/hCG receptor sites than did those from small follicles (Channing \& Kammerman, 1974; Kammerman \& Ross, 1975; Lee, 1976; Stouffer et al., 1976; Nakano et al., 1977; Daguet, 1979; Foxcroft \& Hunter, 1985). The increase in LH/hCG binding 
by granulosa cells was associated with an increase in cAMP production (Lee, 1978; Lindsey \& Channing, 1979). In addition, May \& Schomberg (1984) have shown that the increase in LH/hCG receptor binding by granulosa cells is accompanied by a decrease in FSH-stimulated cAMP production. Presumably, the decreased responsiveness reflects a loss of FSH receptors, inasmuch as it has been shown that reduced FSH binding is associated with luteinization in the rat (Lee \& Takahashi, 1977).

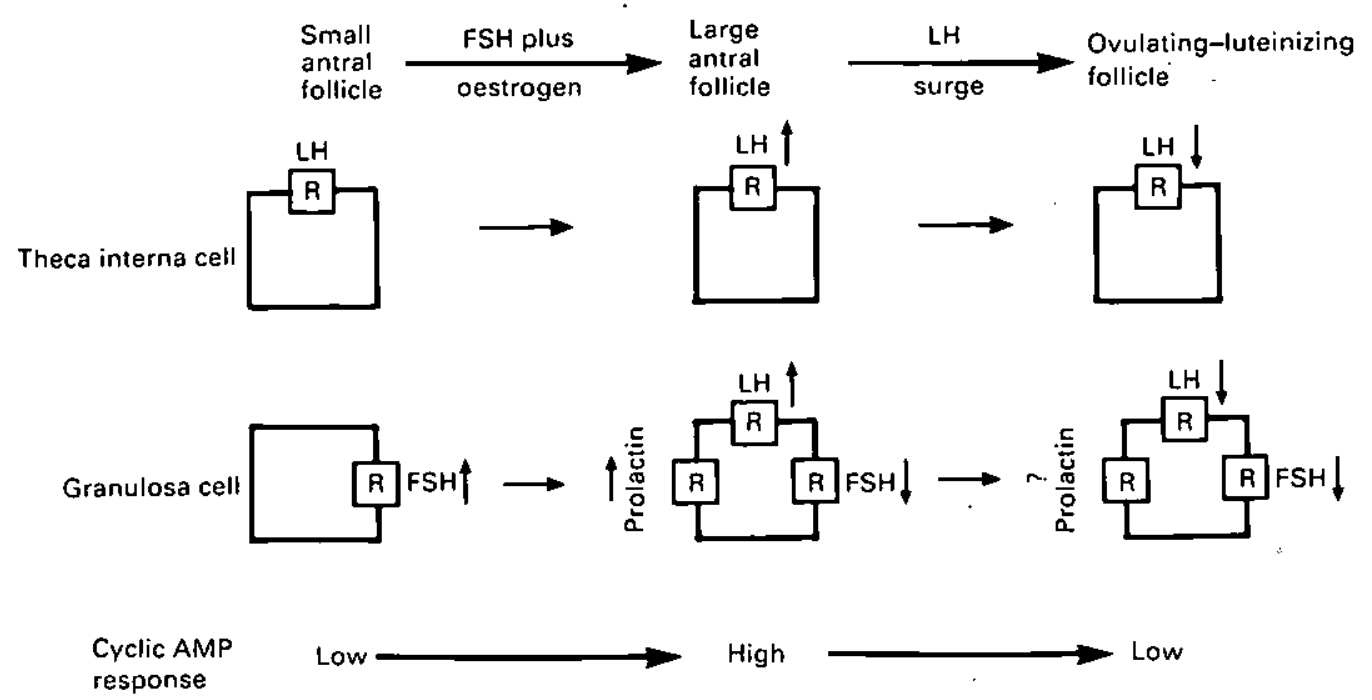

Fig. 1. Schematic illustration of the changes in plasma membrane-bound gonadotrophin and prolactin receptors and in the cyclic AMP response of granulosa and theca interna cells during follicular maturation in the pig. Arrows indicate an increase $(\uparrow)$ or a decrease $(\downarrow)$ in receptor content.

In recent years, FSH-dependent $\mathrm{LH} / \mathrm{hCG}$ receptor induction has been demonstrated for pig granulosa cells in vitro (Channing, 1975; May et al., 1980; Lảarbera \& Ryan, 1981; Loeken \& Channing, 1985). Also, specific prolactin receptors have been found on pig granulosa cells, the specific binding being greater on cells of small $(1-2 \mathrm{~mm})$ than large $(>6 \mathrm{~mm})$ follicles (Rolland \& Hammond, 1975). Further studies (Veldhuis et al., 1980) established that prolactin binding decreased in cultures of granulosa cells from small follicles $(1-2 \mathrm{~mm})$ but increased in cells from large follicles ( $>6 \mathrm{~mm}$ ). Moreover, prolactin was shown to suppress in-vitro progesterone production by granulosa cells from small follicles. However, as the follicle matured, the action of prolactin on granulosa cells became stimulatory (Veldhuis et al., 1981a).

When pig granulosa cells are exposed to $\mathrm{LH} / \mathrm{hCG}$ in vivo they become refractory to acute stimulation by LH/hCG in vitro (Channing et al., 1980; May \& Schomberg, 1984; Tsang et al., 1985). Whether this lack of response is due to a loss of LH-responsive adenylate cyclase (desensitization) or to a decline (down-regulation) in the LH receptor content remains ill-defined. The results of May \& Schomberg (1984) suggest that desensitization occurs after the LH surge. The loss of LH-responsive adenylate cyclase occurs faster than the loss of the LH receptor after exposure to LH/hCG (Jonassen \& Richards, 1980; Jaaskelainen et al., 1980). Thus, one of the first steps in loss of LH responsiveness may be desensitization, followed by a decline in the receptor content.

\section{Interaction of granulosa and theca interna cells in follicular steroidogenesis}

Granulosa and theca interna cells both contribute significantly to oestrogen production in the preovulatory follicle, but granulosa cells synthesize oestrogen in vitro only when supplied with an 
aromatizable androgen or during co-incubation with thecal cells (Anderson et al., 1979; Evans et al., 1981; Haney \& Schomberg, 1981; Stoklosowa et al., 1982; Tsang et al., 1982). Granulosa cells are the major site of progesterone synthesis and are unable to synthesize androgens de novo (Channing \& Tsafriri, 1977; Evans et al., 1981; Tsang et al., 1982). In contrast, theca interna cells are capable of producing substantial quantities of androgen (Evans et al., 1981; Haney \& Schomberg, 1981; Stoklosowa et al., 1982). There is also evidence that granulosa cells may contribute to thecal androgen production by providing a $\mathrm{C}_{21}$ substrate (Lischinsky \& Armstrong, 1983).

In our laboratory, we have examined the changes in follicular fluid concentrations of steroids and the steroidogenic abilities of granulosa and theca interna cells obtained from follicles at various defined times during preovulatory development. The production of oestrogens, androgens and progesterone by dispersed granulosa and theca interna cells from follicles obtained $36 \mathrm{~h}$ and $72 \mathrm{~h}$ after PMSG treatment and $36 \mathrm{~h}$ after hCG treatment (108 $\mathrm{h}$ after PMSG; $\sim 6 \mathrm{~h}$ before ovulation) was measured after short-term incubation in the absence or presence of steroid precursors and pituitary gonadotrophins (Tsang et al., 1985). Theca interna cells produced androgen, predominantly androstenedione, in vitro. This ability to produce androgen increased up to $72 \mathrm{~h}$ after PMSG and was enhanced by the addition of pregnenolone or LH. However, granulosa cells appeared to be incapable of converting $\mathrm{C}_{21}$ steroids to $\mathrm{C}_{19}$ steroids, a finding which was confirmed in a subsequent study (Tsang et al., 1987).

In the absence of aromatizable substrate, oestrogen production by granulosa and theca interna cells was minimal. Addition of androgen to the incubation medium resulted in a marked increase in oestrogen production by granulosa cells, but oestrogen production by theca cells was substantially less at the same substrate concentrations. The ability of both cell types to produce oestrogen increased up to $72 \mathrm{~h}$ after PMSG. Moreover, when granulosa and theca interna cells were incubated together, oestrogen production was greater than the sum of the amounts produced by each cell type when the cells were incubated alone. After exposure to hCG in vivo, both cell types lost the capacity to produce oestrogen, even in the presence of added androgen, suggesting a decrease in aromatase activity. These results clearly indicate that granulosa and thecal cells both contribute to follicular oestrogen production. The rate of production by each cellular compartment appears to depend on the stage of development of the follicle, on the availability of substrate and on aromatase activity. Moreover, the synergism between the cellular components indicates that the granulosa contribution to follicular oestrogen production depends largely on the availability of androgen from the theca.

Both granulosa and theca interna cells produced progesterone in vitro, the rates being enhanced by pregnenolone and dependent on the stage of development of the follicle (Tsang et al., 1985). After exposure to hCG in vivo, thecal cells continued to produce androgen and progesterone but steroid production was no longer influenced by $\mathrm{LH}$ in vitro.

These studies using follicles at well defined stages of preovulatory development, in addition to substantiating previous data, indicate that several functional changes in the steroidogenic abilities of the preovulatory follicle occur during maturation. These changes are the net result of changes in the steroidogenic abilities of the granulosa and thecal cells which occur as the follicles mature. It is also significant that these changes are consistent with the observed pattern of changes in the content of steroids in follicular fluid (Ainsworth et al., 1980).

Our current concepts of follicular steroidogenesis during follicular maturation in the pig are summarized in Fig. 2. In general, the model supports the two-cell, two-gonadotrophin concept of follicular oestrogen synthesis proposed for the rat (reviewed by Hsueh et al., 1984; Erickson et al., 1985). According to this hypothesis, thecal cells, under the influence of LH, synthesize androgens which are transported (presumably by diffusion across the basement membrane) to the granulosa cells where they serve as substrates for oestrogen synthesis under specific stimulation by FSH. Also, the sequence of changes in pituitary hormone receptor content, gonadotrophin-responsive cAMP production and steroid-producing abilities of the granulosa and thecal cells during follicular maturation in the pig are consistent with those described for the rat (Birnbaumer \& Kirchick, 1983). 


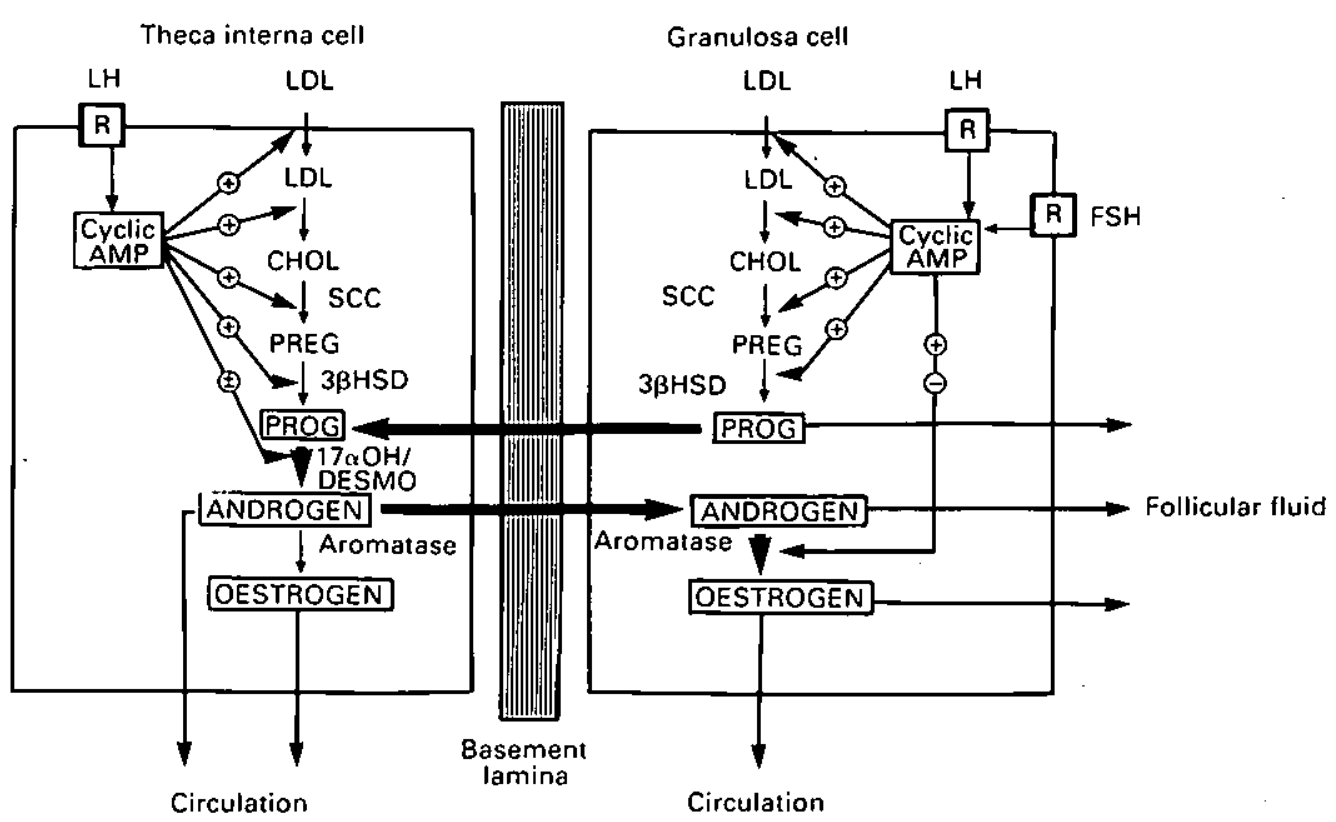

Fig. 2. Current concept of the cellular and hormonal interactions for steroidogenesis during follicular maturation in the pig. Degree of thickness of arrows represents the primary steroids synthesized. Arrows pointing to the steroidogenic pathways indicate whether the enzyme is stimulated $\oplus$ or inhibited $\ominus$ by FSH or LH. Abbreviations: LDL $=$ low density lipoprotein, $\mathrm{CHOL}=$ cholesterol, $\mathrm{PREG}=$ pregnenolone, $\mathrm{PROG}=$ progesterone, $\mathrm{SCC}=$ cholesterol side-chain cleavage enzymes, $3 \beta \mathrm{HSD}=3 \beta$-hydroxysteroid dehydrogenase, $17 \alpha \mathrm{OH} /$ DESMO $=17 \alpha$-hydroxylase and $C_{17-20}$-desmolase, $\mathrm{R}=$ membrane-bound receptor for $\mathrm{FSH}$ or LH.

A major difference between the pig and the rat is that the thecal cell of the pig possesses an active aromatase system. However, it appears that the ability of thecal cells to produce oestrogen is substantially less than that of granulosa cells (Tsang $e t a l ., 1985$ ) and is limited by the level of aromatase activity rather than substrate availability. In contrast, the ability of granulosa cells to synthesize oestrogen is limited by the availability of androgen. It is therefore likely that the granulosa contribution to total follicular oestrogen production in vivo increases significantly as the follicle matures, due to the increase in number of granulosa cells per follicle (Daguet, 1978), the progressive increase in the level of aromatase and the availability of thecal androgen.

It appears that the decline in follicular oestrogen production in the pig after exposure to $\mathrm{LH} / \mathrm{hCG}$ is due primarily to a decrease in the aromatase activity of theca and granulosa cells (Tsang et al., 1985). In the rat ovary the reduction in oestrogen production has been attributed to a decline in the availability of aromatizable androgen, associated with a reduction in the activity of the 17 $\alpha$-hydroxylase/ $C_{17.20}$-desmolase system essential for conversion of $C_{21}$ steroids to androgens (Hamberger et al., 1978; Suzuki \& Tamaoki, 1983; Weiss \& Eckstein, 1983). Whether the decline in follicular oestrogen in the pig is accompanied by changes in the activity of the latter enzyme system remains to be determined.

In steroid-producing tissues, both intra- and extra-cellular sources of cholesterol can be utilized for steroidogenesis. However, in ovarian tissues, extracellular lipoprotein-associated cholesterol is a significant, if not the predominant source of substrate for steroidogenesis in vivo and in vitro (Strauss et al., 1981; Gwynne \& Strauss, 1982). Studies with pig granulosa cells in vitro have shown that pituitary gonadotrophins, oestradiol- $17 \beta$ and somatomedin- $C$ can regulate the uptake and utilization of low-density lipoprotein (Veldhuis et al., 1982b, 1987b, 1988; Veldhuis \& Gwynne, 
1985). It was concluded from these studies that granulosa cell differentiation is regulated, at least in part, by mechanisms involving enhanced activity of lipoprotein-metabolizing pathways.

\section{Intrafollicular actions of steroids}

Clarification of the intrafollicular actions of steroids during follicular maturation has been derived mainly from studies in the rat. Specific binding sites for oestrogens (Richards, 1975; Saiduddin \& Zassenhaus, 1977), androgens (Schreiber et al., 1976; Schreiber \& Ross, 1976) and progesterone (Schreiber \& Erickson, 1979; Naess, 1981) have been identified in rat granulosa cells. These binding sites are believed to be involved in the direct actions of steroids on the follicle itself.

Oestrogens and androgens exert a number of actions on follicular granulosa cells (Table 1) and appear to play a vital role in determining the ultimate fate of the developing follicle (Hsueh $e t a l$, 1984). The role, if any, of progesterone in modulating follicular growth and granulosa cell function is less clear.

There is increasing evidence that the interactions between granulosa and theca interna cells in follicular steroidogenesis are more complex than simply thecal provision of androgen as a precursor for oestrogen synthesis by granulosa cells (Leung \& Armstrong, 1980; Hsueh et al., 1984; Erickson et al., 1985). In-vitro studies with pig follicular cells (Schomberg et al., 1976; Haney \& Schomberg, 1978) have shown that androgens, in general, stimulate progesterone synthesis by granulosa cells. The administration of anti-androgens (flutamide or its hydroxylated metabolite) as a local implant in the ovary of normal cyclic pigs reduced the subsequent production of progesterone by follicular granulosa cells (Schomberg et al., 1978). However, there is also evidence that androgens inhibit basal and FSH-stimulated progesterone production in pig granulosa cells (Lischinsky et al., 1983; Evans et al., 1984) by affecting the conversion of pregnenolone to progesterone. The latter results are in contrast with the finding that, in rat granulosa cell cultures, androgens synergized with FSH to enhance both pregnenolone and progesterone synthesis by stimulating cholesterol side-chain cleavage and $3 \beta$-hydroxysteroid dehydrogenase enzyme activities (Welsh et al., 1982).

Table 1. Effects of oestrogens and androgens on follicular granulosa cells (after Hsueh et al., 1984)

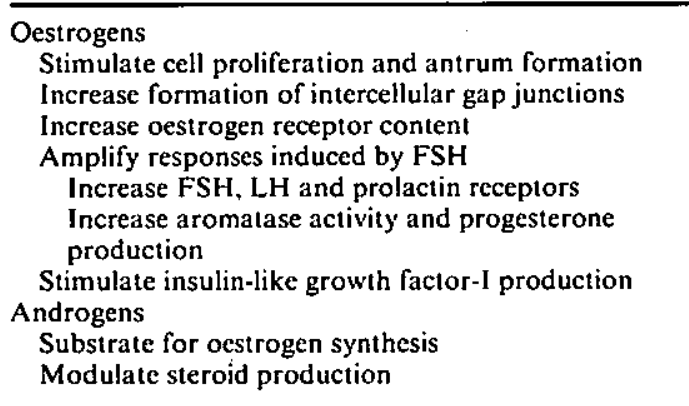

Oestrogens have been shown to stimulate (Goldenberg et al., 1972; Veldhuis et al., 1981b, 1982a) or inhibit (Schomberg et al., 1976; Haney \& Schomberg, 1978; Thanki \& Channing, 1978; Veldhuis et al., 1982b) progesterone production by pig granulosa cells in culture, depending on the duration of oestrogen treatment and the stage of differentiation of the cells. In cultures of immature pig granulosa cells, the stimulatory effect of oestrogen on progesterone production was accompanied by an increase in cytochrome-P450 levels and cholesterol side-chain cleavage activity (Toaff et al., 1983). In addition, oestrogens inhibit androgen production by intact thecal fragments (Tsang et al., 1979b) and progesterone and androgen production by dispersed thecal cells (Hunter \& Armstrong, 1987). 
Oestrogens can also amplify the responses of pig granulosa cells in culture to FSH and LH/hCG. Studies by Veldhuis et al. (1981b, 1982a, b) and Lino et al. (1985) showed that FSH and oestradiol-17 $\beta$ exerted synergistic stimulatory effects on progesterone production by granulosa cells from immature pig follicles. Also, FSH was required for the development of optimal steroidogenic potential and optimal sensitivity to $\mathrm{LH}$ and oestrogen. The increases in progesterone production appeared to be mediated through stimulation of the cholesterol side-chain cleavage activity. Moreover, other studies indicate that oestrogens can enhance prolactin binding and synergize with prolactin in controlling granulosa cell progesterone production (Hammond \& Krall, 1979; Veldhuis et al., 1981a). These studies have elucidated mechanisms whereby oestrogen and pituitary hormones can interact to promote increased progesterone production and broaden our understanding of the endocrine mechanisms that enhance the steroidogenic ability of maturing granulosa-luteal cells during follicular maturation in vivo.

Recent investigations have disclosed a novel regulatory system whereby catechol oestrogens, e.g. 2-hydroxyestradiol-17 $\beta$, synthesized locally from oestradiol-17 $\beta$, can stimulate progesterone production by pig and rat granulosa cells in vitro (Hudson \& Hillier, 1985; Hammond et al., 1986; Spicer et al., 1987; Spicer \& Hammond, 1987a). The use of $\alpha$ - and $\beta$-adrenergic antagonists and antioestrogens indicated that the stimulatory effect of 2-hydroxyoestradiol-17 $\beta$ on progesterone production did not involve adrenergic or oestrogen receptors (Spicer \& Hammond, 1987a, b). Rather, 2-hydroxyoestradiol-17 $\beta$ synergized with $\beta$-adrenergic agonists (Spicer \& Hammond, $1987 \mathrm{~b}$ ) and enhanced progesterone production of granulosa cells stimulated by $\beta$-adrenergic agonists by increasing the number of $\beta$-adrenergic binding sites (Spicer \& Hammond, 1988a). More recently, Spicer \& Hammond (1989) showed that 2-hydroxyoestradiol-17 $\beta$ but not oestradiol-17 $\beta$ itself enhanced cAMP production stimulated by catecholamines and FSH and that gonadotrophins could substitute for catecholamines in amplifying the effects of 2 -hydroxyoestradiol-17 $\beta$. Overall, these studies suggest a complex and potentially important intrafollicular regulatory system involving gonadotrophins, catechol oestrogens and catecholamines. Also, it appears that the mechanism by which 2-hydroxyoestradiol-17 $\beta$ potentiates the stimulatory effects of gonadotrophins and catecholamines on pig granulosa cell progesterone production differs from that of oestradiol-17 $\beta$ and androgens (Spicer \& Hammond, 1988b, 1989).

The studies detailed above indicate that steroids can exert a direct intrafollicular action by modulating their own production (Fig. 3). Thus, thecal androgens not only serve as substrates for oestrogen synthesis by granulosa cells but also play a paracrine role in the regulation of granulosa cell steroidogenesis. Oestrogen produced by the theca and granulosa celis can also exert an autocrine control on follicular steroidogenesis by a local negative feedback to control the synthesis of its own precursor. However, further studies are needed before we can assess the significance of these intrafollicular control mechanisms in regulating follicular steroidogenesis.

It is also significant that FSH, LH and oestradiol-17 $\beta$ stimulate production of insulin-like growth factor-I by pig granulosa cells in vitro (Hsu \& Hammond, 1987). This finding raises the possibility that the growth-promoting effects of these hormones are mediated through regulation of the secretion of agents such as insulin-like growth factors (Hammond $e t$ al., 1988).

It has been proposed that progesterone has an obligatory role in the rupture of the sheep follicle by facilitating the synthesis of prostaglandin F-2 $\alpha$ through enhancement of follicular prostaglandin E-2-9-keto-reductase activity (Murdoch et al., 1986). In turn, prostaglandin F-2 $\alpha$ enhances follicular collagenolytic activity, on which ovulation is thought to depend. Whether progesterone exerts such an action in the pig follicle remains to be explored.

\section{Prostaglandins and ovulation}

Studies in our laboratory have provided convincing evidence that prostaglandins (PG) play a vital role in the ovulatory process of the pig. We have shown that preovulatory follicular development is 


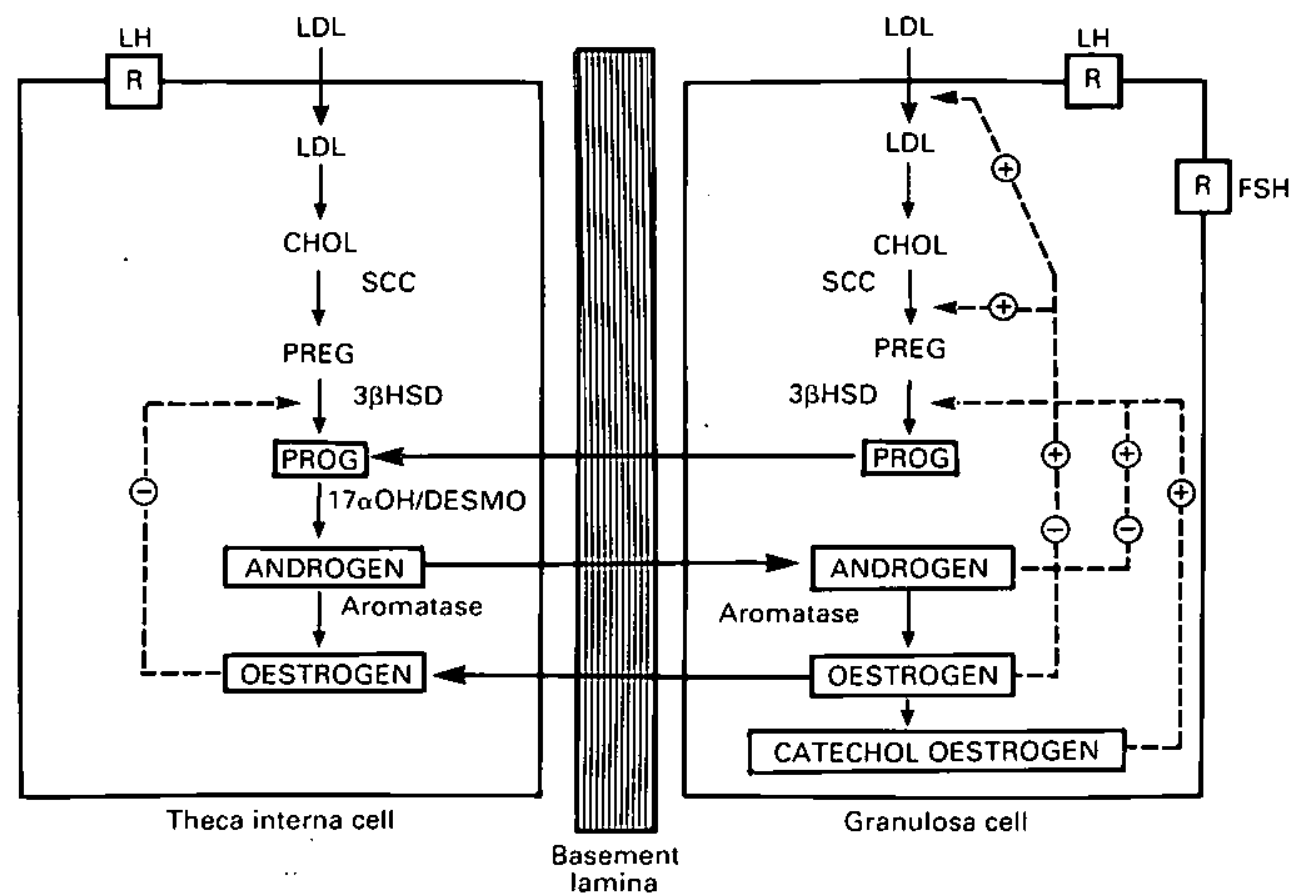

Fig. 3. Autocrine and paracrine regulation of follicular stcroidogenesis by steroid hormones. Dotted lines represent the intrafollicular regulation of steroidogenesis by steroid hormones and $\oplus$ stimulation or $\Theta$ inhibition of the enzyme. Abbreviations are as detailed in Fig. 2.

associated with a marked increase in intrafollicular levels of PGE-2 and PGF-2 $\alpha$ shortly before ovulation (Ainsworth et al., 1975; Tsang et al., 1979a). The increases were restricted to those follicles which appeared destined to ovulate. Indomethacin, an inhibitor of PG synthesis, suppressed the preovulatory rise in PGs and blocked ovulation. However, other ovarian responses known to occur as a result of $\mathrm{LH} / \mathrm{hCG}$ action, i.e. oocyte maturation, luteinization and increased progesterone production, were not prevented by indomethacin treatment (Ainsworth et al., 1979). Moreover, the indomethacin blockade of ovulation could be overcome by the administration of PGF-2 $\alpha$ but not PGE-2, shortly before the time of predicted ovulation (Downey \& Ainsworth, 1980). These results support those obtained with other species (Armstrong, 1981) and suggest that an increase in intrafollicular amounts of prostaglandins in response to LH is a prerequisite for follicular rupture.

\section{Follicular synthesis of prostaglandins}

To establish more firmly that PGs play a role in the processes leading to follicular rupture, it has to be shown that they are formed in the follicle. Indeed, this is the case. Using the PMSG/hCGtreated gilt, it was shown that granulosa cells and theca interna tissues isolated from follicles before or after hCG administration produced PGE-2 and PGF-2 $\alpha$ in vitro (Evans et al., 1983; Ainsworth et al., 1984; Tsang et al., 1988). Both cell types can also produce 6-ketoprostaglandin-Fla, the stable metabolite of prostacyclin (Veldhuis et al., 1982c; Evans et al., 1983). Before exposure to $\mathrm{LH} / \mathrm{hCG}$ in vivo, thecal cells were the primary source of PG production (Table 2). After exposure to $\mathrm{LH} / \mathrm{hCG}$ in vivo, the production of PGs by follicular cells increased markedly, with the granulosa cells being largely responsible for the increase. It is also significant that the increase in PG production by granulosa cells was associated with a preferential increase in PGF- $2 \alpha$ production (Tsang et al., 1988). This change in the PGE/PGF ratio (Table 2) is consistent with the hypothesis that a change in the relative levels of PGE-2 and PGF-2 $\alpha$ is important as a determinant factor in follicular 
rupture (Murdoch, 1985). It is also consistent with the observation that PGF-2 $\alpha$ is more effective than PGE-2 in overcoming the indomethacin-induced block of ovulation (Downey \& Ainsworth, 1980).

Table 2. In-vitro production of PGE-2 and PGF-2 $\alpha$ by isolated granulosa and theca interna cells from pig follicles before and after exposure to hCG in vivo* (from Tsang et al., 1988)

\begin{tabular}{lccc}
\hline & \multicolumn{3}{c}{ Prosiaglandin production } \\
\cline { 2 - 4 } Cultures & $\begin{array}{c}\text { PGE-2 } \\
\left(\mathrm{ng} / 10^{5} \text { cells }\right)\end{array}$ & $\begin{array}{c}\text { PGF-2a } \\
\left(\mathrm{ng} / 10^{5} \text { cells }\right)\end{array}$ & $\begin{array}{c}\text { PGE-2/PGF-2a } \\
\text { ratio }\end{array}$ \\
\hline $\begin{array}{c}\text { Granulosa cells } \\
72 \mathrm{~h} \text { after PMSG }\end{array}$ & $2.26 \pm 0.43$ & $0.05 \pm 0.007$ & $51.93 \pm 11.66$ \\
$108 \mathrm{~h}$ after PMSG & $26.7 \pm 4.1^{\circ}$ & $1.55 \pm 0.23^{\circ}$ & $19.48 \pm 3.58^{\circ}$ \\
Theca interna cells & & & \\
$72 \mathrm{~h}$ after PMSG & $8.30 \pm 1.70^{\circ}$ & $0.71 \pm 0.09^{\mathrm{b}}$ & $10.72 \pm 1.16$ \\
$108 \mathrm{~h}$ after PMSG & $15.0 \pm 4.1^{\mathrm{ac}}$ & $1.2 \pm 0.21^{\circ}$ & $12.03 \pm 1.45$ \\
\hline
\end{tabular}

Values are mean \pm s.e.m. $(n=12,4$ replicate experiments $)$.

* Cells were cultured in Minimal Essential Medium for $12 \mathrm{~h}$.

'Significantly different from the same cell type $72 \mathrm{~h}$ after treatment with PMSG $(P<0.025)$.

bSignificantly different from granulosa cells $72 \mathrm{~h}$ after PMSG $(P<0.01)$.

'Significantly different from granulosa cells $108 \mathrm{~h}$ after PMSG $(P<0.05)$.

It has been suggested that $\mathrm{LH} / \mathrm{hCG}$ may regulate follicular PG production by two different, but complementary actions, i.e. by increasing the availability of arachidonic acid through the activation of lipolytic enzymes and by increasing prostaglandin synthétase activity (Tsang $e t$ al., 1988). Both actions depend on the cell type and stage of differentiation of the follicle. There is also evidence to suggest that both the $\mathrm{Ca}^{2+}$-polyphosphoinositol-protein kinase $\mathrm{C}$ second messenger system and the CAMP-protein kinase A system are involved in the regulation of follicular prostaglandin production in response to LH/hCG (Dimino et al., 1987; Velduis et al., 1987a; Tsang et al., 1988). However, the relative importance of these systems in mediating the actions of LH remains to be investigated.

Formation of biologically active arachidonate metabolites other than PGE-2, PGF-2 $\alpha$ and prostacyclin in the pig follicle in response to $\mathrm{LH} / \mathrm{hCG}$ has not been demonstrated. However, studies in the rat have shown that inhibitors of lipoxygenase activity block ovulation and follicular lipoxygenase activity and that lipoxygenase activity in the follicle is enhanced by hCG (Reich et al., 1983, 1985a). These studies suggest that products of the lipoxygenase and the cyclo-oxygenase pathways of the arachidonic acid cascade (Fig. 4) may be involved in follicular rupture. Also, increases in thromboxane B-2 (the stable metabolite of thromboxane A-2) concentrations have been demonstrated during the periovulatory period in sheep follicular tissue and follicular fluid (Murdoch, 1986) and in the preovulatory rat ovary (Brown \& Poyser, 1984).

\section{Intrafollicular actions of prostaglandins}

While a physiological role for prostaglandins in ovulation has been established, the mechanism by which they act to promote follicular rupture is not well understood. Various theories have been put forward proposing local prostaglandin-regulated metabolic actions affecting the follicle wall. Ovulation is associated with increases of proteolytic enzymes, including plasminogen activator in the follicle (Beers et al., 1975; Strickland \& Beers, 1976; Reich et al., 1985b; Liu et al., 1987) and collagenase (Morales et al., 1983; Reich et al., 1985c). Prostaglandins have been implicated in the activation, synthesis and/or release of proteolytic enzymes because the increases in the levels of 


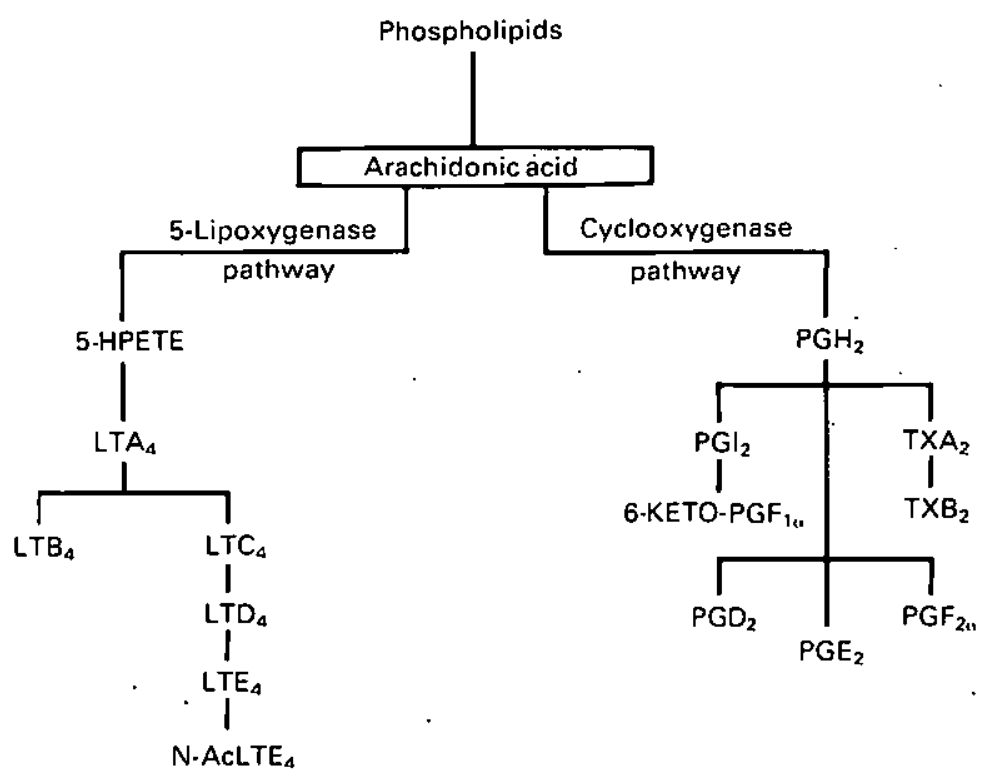

Fig. 4. Formation of prostaglandins, thromboxanes and leukotrienes from arachidonic acid. Abbreviations: 5-HPETE $=$ 5-hydroperoxy-6,8,11,14-eicosatetraenoic acid; PG = prostaglandin; TX $=$ thromboxane; $\mathrm{LT}=$ leukotriene; $\mathrm{N}$-AcLT $=\mathrm{N}$-acetyl-leukotriene.

these enzymes in the follicle follow a pattern similar to that of the prostaglandins (Espey, 1980). It is also possible that prostaglandins play a role in the increased smooth muscle activity in the follicle wall observed around the time of ovulation, or induce microcirculatory changes in the follicle wall (Lindner et al., 1977).

Ovulation is also associated with vasodilatation, hyperaemia, oedema and extravasation (Parr, 1974, 1975). All of these phenomena are associated with tissue inflammation. Thus, eicosanoids such as thromboxane A-2 and leukotrienes (the principal lipoxygenase-derived products of the arachidonic acid cascade), which have been identified in preovulatory follicles, may also have a role in ovulation. Thromboxane A-2 is a potent platelet aggregator and contractor of smooth muscle (Silver, 1981). It could potentiate ovulation by increasing the contractility of ovarian smooth muscle and cause formation of microthrombi which, in conjunction with vasoconstriction, could produce ischaemia which is associated with follicular rupture. Leukotrienes are inflammatory agents which could produce localized changes in follicular microcirculation and haemodynamics such as chemotaxis, vasodilatation and extravasation (Piper, 1984; Feuerstein \& Hallenbeck, 1987).

\section{References}

Ainsworth, L., Baker, R.D. \& Armstrong, D.T. (1975) Preovulatory changes in follicular fluid prostaglandin F levels in swine. Prostaglandins 9, 915-925.

Ainsworth, L., Tsang, B.K., Downey, B.R., Baker, R.D., Marcus, G.J. \& Armstrong, D.T. (1979) Effects of indomethacin on ovulation and luteal function in gilts. Biol. Reprod. 21, 401-411.

Ainsworth, L., Tsang, B.K., Downey, B.R., Marcus, G.J. \& Armstrong, D.T. (1980) Interrelationships between follicular fluid steroid levels, gonadotropic stimuli. and oocyte maturation during preovulatory development of porcine follicles. Biol. Reprod. 23, 621-627.
Ainsworth, L., Tsang, B.K., Downey, B.R., Marcus, G.J. \& Amstrong, D.T. (1982) The PMSG/hCG treated prepubertal gilt as a model for the study of the actions and interactions of pituitary and ovarian hormones on follicular cell differentiation. In Follicular Maturation and Ovulation, pp. 97-102. Eds R. Rolland, E. V. van Hall, S. G. Hillier, K. P. McNalty \& J. Schoemaker. Excerpta Medica, Amstcrdam.

Ainsworth, L., Tsang, B.K., Marcus, G.J. \& Downey, B.R. (1984) Prostaglandin production by dispersed granulosa and theca interna cells from porcine preovulatory follicles. Biol. Reprod. 31, 115-121. 
Anderson, L.D., Schaerf, F.W. \& Channing, C.P. (1979) Effects of follicular development on the ability of cultured porcine granulosa cells to convert androgens to estrogens. In Ovarian Follicular and Corpus Luteum Function, pp. 187-195. Eds C. P. Channing, J. Marsh \& W. A. Sadler. Plenum Press, New York.

Armstrong, D.T. (1981) Prostaglandins and follicular functions. J. Reprod. Fert. 62, 283-291.

Beers, W.H., Strickland, S. \& Reich, E. (1975) Ovarian plasminogen activator; relationship to ovulation and hormonal regulation. Cell 6, 387-394.

Birnbaumer, L. \& Kirchick, H.J. (1983) Regulation of gonadotropic action: the molecular mechanisms of gonadotropin-induced activation of ovarian adenyly! cyclases. In Factors Regulating Ovarian Function, pp. 287-310. Eds G. S. Greenwald \& P. F. Terranova. Raven Press, New York.

Brown, C.G. \& Poyser, N.L. (1984) Studies on ovarian prostaglandin production in relation to ovulation in the rat. J. Reprod. Fert. 72, 407-4I4.

Channing, C.P. (1975) Follicle stimulating hormone stimulation of $\left[{ }^{125} \mathrm{I}\right]$-human chorionic gonadotropin binding in porcine granulosa cell culture. Proc. Soc. exp. Biol. Med. 149, 238-241.

Channing, C.P. \& Kammerman, S. (1974) Binding of gonadotropins to ovarian cells. Biol. Reprod. 10, 179-198.

Channing, C.P. \& Ledwitz-Rigby, F. (1975) Methods for assessing hormone-mediated differentiation of ovarian cells in culture and short-term incubations. In Methods in Enzynology. Vol. 39, pp. 183-230. Eds J. G. Hardman \& B. W. O'Malley. Academic Press, New York.

Channing, C.P. \& Tsafriri, A. (1977) Mechanism of action of luteinizing hormone and follicle-stimulating hormone on the ovary in vitro. Metabolism 26, 413-468.

Channing, C.P., Brinkley, H.J. \& Young, E.P. (1980) Relationship between scrum luteinizing hormone levels and the ability of porcine granulosa cells to respond to exogenous luteinizing hormone in culture. Endocrinology 106, 317-322.

Daguet, M.C. (1978) Some aspects of final follicle growth in the sow. Annls Biol. anim. Biochim. Biophys. 18, 1343-1349.

Daguet, M-C. (1979) Increase of follicle cell LH binding and changes in the LH level of follicular fluid during the preovulatory period in the sow. $A n n / s$ Biol anim. Biochim. Biophys. 19, 1655-1667.

Dimino, M.J., Snitzer, J. \& Brown, K.M. (1987) Inositol phosphates accumulation in ovarian granulosa after stimulation by luteinizing hormone. Biol. Reprod. 37, 1129-1134.

Downey, B.R. \& Ainsworth, L. (1980) Reversal of indomethacin blockade of ovulation in gilts by prostaglandins. Prostaglandins 19, 17-22.

Erickson, G.F., Magoffin, D.A., Dyer, C.A. \& Hafeditz, C. (1985) The ovarian androgen producing cells: A review of structure/function relationships. Endocr. Rev. 6, 371-399.

Espey, L.L. (1980) Ovulation as an inflammatory reaction-a hypothesis. Biol. Reprod. 22, 73-106.

Evans, G., Dobias, M., King, G.J. \& Armstrong, D.T. (1981) Estrogen, androgen, and progesterone bio- synthesis by theca and granulosa of preovulatory follicles in the pig. Biol. Reprod. 25, 673-682.

Evans, G., Dobias, M., King, G.J. \& Armstrong, D.T. (1983) Production of prostaglandins by porcine preovulatory follicular tissue and their role in intrafollicular function. Biol. Reprod. 28, 322-328.

Evans, G., Lischinsky, A.L., Daniel, S.A.J. \& Armstrong, D.T. (1984) Androgen inhibition of FSH-stimulated progesterone production by granulosa cells of prepubertal pigs. Can.J. Physiol. Pharmacol.62,840-845.

Feuerstein, G. \& Hallenbeck, J.M. (1987) Prostaglandins, lcukotrienes and platelet activating factor in shock. Ann. Rev. Pharmacol. Toxicol. 27, 301-313.

Foxcroft, G.R. \& Hunter, M.G. (1985) Basic physiology of follicular maturation in the pig. J. Reprod. Fert., Suppl. 33, 1-19.

Goldenberg, R.L., Bridson, W.E. \& Kohler, P.O. (1972) Estrogen stimulation of progesterone synthesis by porcine granulosa cells in culturc. Biochem. Biophys. Res. Commun. 48, 101-107.

Gwynne, J.T. \& Strauss, J.F., III (1982) The role of lipoproteins in steroidogenesis and cholesterol metabolism in steroidogenic cells. Endocr. Rev. 3, 299-329.

Hamberger, L., Hillensjo, T. \& Ahren, K. (1978) Steroidogenesis in isolated cells of preovulatory rat follicles. Endocrinology 103, 771-777.

Hammond, J.M. \& Krall, E. (1979) Steroid hormones modulate prolactin binding by cultured porcine granulosa cells. Biochem. Biophys. Res. Commun. 91, 284-288.

Hammond, J.M., Hersey, R.M., Walega, M.A. \& Weisz, J. (1986) Catechol-estrogen production by porcine ovarian cells. Endocrinology 118, 2292-2299.

Hammond, J.M., Hsu, C-J., Klindt, J., Tsang, B.K. \& Downey, B.R. (1988) Gonadotropins increase concentrations of immunoreactive insulin-like growth factor-1 in porcine follicular fluid in vivo. Biol. Reprod. 38, 304-308.

Haney, A.F. \& Schomberg, D.W. (1978) Steroidal modulation of progesterone secretion by granulosa cells from large porcine follicles: a role for androgens and estrogens in controlling steroidogenesis. Biol. Reprod. 19, 242-248.

Haney, A.F. \& Schomberg, D.W. (1981) Estrogen and progesterone production by developing porcine follicles in vitro: evidence for estrogen formation by theca. Endocrinology 109, 971-977.

Hsu, C.-J. \& Hammond, J.M. (1987) Gonadotropins and estradiol stimulate immunoreactive insulin-like growth factor-I production by porcine granulosa cells in vitro. Endocrinology' 120, 198-207.

Hsueh, A.J.W., Adashi, E.Y., Jones, P.B.C. \& Welsh, T.H., Jr (1984) Hormonal regulation of the differentiation of cultured ovarian granulosa cells. Endocr. Rev. 5, 76-127.

Hudson, K.E. \& Hillier, S.G. (1985) Catechol oestradiol control of FSH-stimulated granulosa cell steroidogenesis. J. Endocr. 106, R I-R4.

Hunter, M.G. \& Armstrong, D.T. (1987) Oestrogens inhibit steroid production by dispersed porcine thecal cells. Molec. cell. Endocr. 50, 165-1 70.

Ireland, J.J. (1987) Control of ovarian follicular growth and development. J. Reprod. Fert., Suppl. 34, 39-54. 
Jaaskelainen, K., Hyvonen, T. \& Rajaniemi, H. (1980) Human choriogonadotrophin induced desensitisation of granulosa cell adenylate cyclase to gonadotrophins and loss of $\mathrm{LH} / \mathrm{hCG}$ receptors. Molec. cell. Endocr. $20,145-156$.

Jonassen, J.A. \& Richards, J.S. (1980) Granulosa cell desensitisation; effects of gonadotropins on antral and preantral follicles. Endocrinology 106, 1786-1794.

Kammerman, S. \& Ross, J. (1975) Increase in numbers of gonadotropin receptors on granulosa cells during follicular maturation. J. clin. Endocr. Metab. 41, 546-550.

LaBarbera, A.R. \& Ryan, R.J. (1981) Porcine granulosa cells in suspension culture. 1. Follicle-stimulating hormone induction of human chorionic gonadotropin-binding sites on cells from small follicles. Endocrinology 108, 1561-1570.

Lee, C.Y. (1976) The porcine ovarian follicle. III. Development of chorionic gonadotropin receptors associated with increase in adenyl cyclase aclivity during follicle maturation. Endocrinology 99, 42-48.

Lee, C.Y. (1978) Adenylate cyclase of porcine granulosa celis: Differential responses to gonadotropins during follicle maturation. Endocrinology 103, 1153-1158.

Lee, C.Y. \& Takahashi, H. (1977) Follicle-stimulating hormone receptors in rat ovaries; decrease in numbers of binding sites associated with luteinization. Endocrinology 101, 869-875.

Leung, P.C.K. \& Armstrong, D.T. (1980) Interactions of steroids and gonadotropins in the control of steroidogenesis in the ovarian follicle. Ann. Rev. Physiol. 42, 71-82.

Lindner, H.R., Amsterdam, A., Salomon, Y., Tsafriri, A., Nimrod, A., Lamprecht, S.A., Zor, U. \& Koch, Y. (1977) Intraovarian factors in ovulation; determinants of follicular response to gonadotrophins. $J$. Reprod. Fert. 51, 215-235.

Lindsey, A.M. \& Channing, C.P. (1979) Influence of follicular maturation upon the effect of ovine follicle stimulating hormone and luteinizing hormone upon cyclic AMP accumulation by isolated porcine granulosa cells. Biol. Reprod. 20, 473-482.

Lino, J., Baranao, S. \& Hammond, J.M. (1985) Multihormone regulation of steroidogenesis in cultured porcine granulosa cells: studies in serum-free medium. Endocrinology 116, 2143-215!.

Lischinsky, A. \& Armstrong, D.T. (1983) Granulosa cell stimulation of thecal androgen synthesis. Can. J. Physiol. Pharmacol. 61, 472-477.

Lischinsky, A., Evans, G. \& Armstrong, D.T. (1983) Site of androgen inhibition of follicle-stimulating hormonestimulated progesterone production in porcine granulosa cells. Endocrinology 113, 1999-2003.

Liu, Y-X., Cajander, S.B., Ny, T., Kristensen, P. \& Hsueh, A.J.W. (1987) Gonadotropin regulation of tissue-type and urokinase-type plasminogen activators in rat granulosa and theca-interstitial cells during the periovulatory period. Molec. cell. Endocr. 54, 221-229.

Loeken, M.R. \& Channing, C.P. (1985) Direct evidence for de-novo synthesis of LH receptors in cultured pig granulosa cells in response to FSH. J. Reprod. Ferl. 73, 343-35I.

Marcus, G.J., Connor, L., Domingo, M.T., Tsang, B.K., Downey, B.R. \& Ainsworth, L. (1984) Enzymatic dissociation of ovarian and uterine tissues. Endocr. Res. 10, $151-162$.

May, J.V. \& Schomberg, D.W. (1984) Developmental coordination of luteinizing hormone/human chorionic gonadotropin (hCG) receptors and acute hCG responsiveness in cultured and freshly harvested porcine granulosa cells. Endocrinology 114, 153-163.

May, J.V., McCarty, K., Jr, Reichert, L.E., Jr \& Schomberg, D.W. (1980) Follicle-stimulating hormone-mediated induction of functional luteinizing hormone/human chorionic gonadotropin receptors during monolayer culture of porcine granulosa cells. Endocrinology 107, 1041-1049.

Morales, T.I., Woessner, J.F., Marsh, J.M. \& LeMaire, W.J. (1983) Collagen, collagenase and collagenolytic activity in rat graafian follicles during follicular growth and ovulation. Biochim. Biophys. Acia 119, 756-759.

Murdoch, W.J. (1985) Follicular determinants of ovulation in the ewe. Dom. Anim. Endocrinol. 2, 105-121.

Murdoch, W.J. (1986) Accumulation of thromboxane $\mathrm{B}_{2}$ within periovulatory ovine follicles; relationship to adhesion of platelets to endothelium. Prostaglandins 32, 597-604.

Murdoch, W.J., Peterson, T.A., Van Kirk, E.A., Vincent, D.L. \& Inskeep, E.K. (1986) Interactive roles of progesterone, prostaglandins and collagenase in the ovulatory mechanism of the ewe. Biol. Reprod. 35, 1187-1194.

Naess, O. (1981) Characterization of cyloplasmic progesterone receptors in rat granulosa cells. Evidence for nuclear translocation. Acta endocr., Copenh. 98, 288-294.

Nakano, R., Akahori, T., Katayama, K. \& Tojo, S. (1977) Binding of $\mathrm{LH}$ and FSH to porcine granulosa cells during follicular maturation. J. Reprod. Fert. 51, 23-27.

Parr, E.L. (1974) Histological examination of the rat ovarian follicle wall before ovulation. Biol. Reprod. $11,483-503$.

Parr, E.L. (1975) Rupture of ovarian follicles at ovulation. J. Reprod. Fert., Suppl. 22, 1-22.

Piper, P.J. (1984) Formation and actions of leukotrienes. Physiol. Rev. 64, 744-761.

Reich, R., Kohen, F., Naor, Z. \& Tsafriri, A. (1983) Possible involvement of lipoxygenase products of arachidonic acid pathway in ovulation. Prostaglandins 26, $1011-1020$.

Reich, R., Kohen, F., Slager, R. \& Tsafriri, A. (1985a) Ovarian lipoxygenase activity and its regulation by gonadotropin in the rat. Prostaglandins 30, 581-590.

Rejch, R., Miskin, R. \& Tsafriri, A. (1985b) Follicular plasminogen activator. Involvement in ovulation. Endocrinology 116, 516-521.

Reich, R., Tsafriri, A. \& Mechanic, G.L. (1985c) The involvement of collagenolysis in ovulation in the rat. Endocrinology 116, 522-527.

Richards, J.S. (1975) Estradiol receptor content in rat granulosa cells during follicular development: modification by estradiol and gonadotropins. Endocrinology 97, 1174-1184.

Richards, J.S. (1980) Maturation of ovarian follicles: actions and interactions of pituitary and ovarian hormones on follicular cell differentiation. Physiol. Rev. $60,51-89$. 
Rolland, R. \& Hammond, J.M. (1975) Demonstration of specific receptor for prolactin in porcine granulosa celis. Endocr. Res. Commun. 2, 281-298.

Saiduddin, S. \& Zassenhaus, H.P. (1977) Estradiol-17ß receptors in the immature rat ovary. Steroids 29, 197-213.

Schomberg, D.W., Stouffer, R.L. \& Tyrey, L. (1976) Modulation of progestin secretion in ovarian cells by $17 \beta$-hydroxy-5a-androstan-3-one (dihydrotestosterone): a direct demonstration in monolayer culture. Biochim. Biophys. Res. Commun. 68, 77-81.

Schomberg, D.W., Williams, R.F., Tyrey, L. \& Ulberg, L.C. (1978) Reduction of granulosa cell progesterone secretion in vitro by intraovarian implants of antiandrogen. Endocrinology 102, 984-987.

Schreiber, J.R. \& Erickson, G.F. (1979) Progesterone receptor in the rat ovary: further characterization and localization in the granulosa cell. Steroids 34, 459-469.

Schreiber, J.R. \& Ross, G.T. (1976) Further characterization of a rat ovarian testosterone receptor with evidence for nuclear translocation. Endocrinology 99, 590-596.

Schreiber, J.R., Reid, R. \& Ross, G.T. (1976) A receptorlike testosterone-binding protein in ovaries from estrogen-stimulated hypophysectomized immature female rats. Endocrinology 98, 1206-1213.

Silver, M.J. (1981) Mechanisms of hemostasis and therapy of thrombosis: new concepts based on the metabolism of arachidonic acid by platelets and endothelial cells. Adv. Pharmacol. Chemorher. 18, 1-47.

Spicer, L.J.\& Hammond, J.M. (1987a) Catecholestrogens stimulatc progestin secretion by cultured porcinc granulosa cells. Molec. cell. Endocr. 50, 139-147.

Spicer, L.J. \& Hammond, J.M. (1987b) 2-Hydroxyestradiol modulates a facilitative action of catecholamines on porcine granulosa cells. Endocrinology 120 , 2375-2382.

Spicer, L.J. \& Hammond, J.M. (1988a) Effects of 2hydroxyestradiol on the number of granulosa cell $\beta$. adrenergic receplors. Endocrinology 122, 2710-2717.

Spicer, L.J. \& Hammond, J.M. (1988b) Comparative effects of androgens and catecholestrogens on progesterone production by porcine granulosa cells. Molec. cell. Endocr. 56, 211-217.

Spicer, L.J. \& Hammond, J.M. (1989) Mechanism of action of 2-hydroxyestradiol on steroidogenesis in ovarian granulosa cells; interactions with catecholamines and gonadotropins involve cyclic adenosine monophosphate. Biol. Reprod. 40, 87-95.

Spicer, L.J., Walega, M.A. \& Hammond, J.M. (1987) Metabolism of [ $\left.{ }^{3} \mathrm{H}\right]$ 2-hydroxyestradiol by cultured porcine granulosa cells: evidence for the presence of a catechol-O-methyl transferase pathway and a direct stimulatory effect of 2-methyoxyestradiol on progesterone production. Biol. Reprod. 36, $562-571$.

Stoklosowa, S., Bahr, J. \& Gregoraszczuk, E. (1978) Some morphological and functional characteristics of cells of the porcine theca interna in tissue culture. Biol. Reprod. 19, 712-719.

Stoklosowa, S., Gregoraszczuk, E. \& Channing, C.P. (1982) Estrogen and progesterone secretion by isolated cultured porcine thecal and granulosa cells. Biol. Reprod. 26, 943-952.
Stouffer, R.L., Tyrey, L. \& Schomberg, D.W. (1976) Changes in [ $\left.{ }^{123}\right]$-labeled human chorionic gonadotropin binding to porcine granulosa cells during follicle development and cell culture. Endocrinology 99, 516-524.

Strauss, J.F., IIl, Schuler, L.A., Rosenblum, M.F. \& Tanaka, T. (1981) Cholesterol metabolism by ovarian tissue. Adv. Lipid Res. 18, 99-157.

Strickland, S. \& Beers, W.H. (1976) Studies on the role of plasminogen activator in ovulation. $J$. biol. Chem. 251, 5694-5702.

Suzuki, K. \& Tamaoki, B. (1983) Acute decrease by human chorionic gonadotropin of the activity of preovulatory ovarian 17a-hydroxylase and C-17-C. 20 lyase is due to decrease of microsomal cylochrome P-450 through de novo synthesis of ribonucleic acid and protein. Endocrinology 113, 1985-1991.

Thanki, K.H. \& Channing, C.P. (1978) Effect of folliclestimulating hormone and estradiol upon progesterone secretion by porcine granulosa cells in tissue culture. Endocrinology 103, 74-80.

Toaff, M.E., Strauss, J.F., III \& Hammond, J.M. (1983) Regulation of cytochrome P450 SCC in immature porcine granulosa cells by FSH and estradiol. Endocrinology' 112, I156-1157.

Tsang, B.K., Ainsworth, L., Downey, B.R. \& Armstrong, D.T. (1979a) Preovulatory changes in cyclic AMP and prostaglandin concentrations in follicular fluid of gilts. Prostaglandins 17, 141-148.

Tsang, B.K., Leung, P.C.K. \& Armstrong, D.T. (1979b) Inhibition by estradiol- $7 \beta$ of porcine thecal androgen production in vitro. Molec. cell. Endocr. 14, 131-139.

Tsang, B.K., Moon, Y.S. \& Armstrong, D.T. (1982) Estradiol $-17 \beta$ and androgen secretion by isolated porcine ovarian follicular cells in vitro. Can. J. Physiol. Pharmacol. 60, 1112-1118.

Tsang, B.K., Ainsworth, L., Downey, B.R. \& Marcus, G.J. (1985) Differential production of steroids by dispersed granulosa and theca interna cells from developing preovulatory follicles of pigs. $J$. Reprod. Fert. 74, 459-47!.

Tsang, B.K., Taheri, A., Ainsworth, L. \& Downey, B.R. (1987) Secretion of $17 \alpha$-hydroxyprogesterone, androstenedione and estrogens by porcine granulosa and theca interna cells in culture. Can. J. Physiol. Pharmacol. 65, 1951-1956.

Tsang, B.K., Arodi, J., Li, M., Ainsworth, L., Srikandakumar, A. \& Downey, B.R. (1988) Gonadotropic regulation of prostaglandin production by ovarian follicular cells of the pig. Biol. Reprod. 38, 627-635.

Veldhuis, J.D. \& Gwynne, J.T. (I985) Estrogen regulates low-density lipoprotein metabolism by cultured swine granulosa cells. Endocrinology 117, 1321-1327.

Veldhuis, J.D., Klase, P.A. \& Hammond, J.M. (1980) Divergent effects of prolactin upon steroidogenesis by porcine granulosa cells in vitro; influence of cytodifferentiation. Endocrinology 107, 42-46.

Veldhuis, J.D., Klase, P.A. \& Hammond, J.M. (1981a) Sex steroids modulate prolactin action in spontaneously luteinizing porcine granulosa cells in vitro. Endocrinology 108, 1463-1468. 
Veldhuis, J.D., Klase, P.A. \& Hammond, J.M. (198Ib) Direct actions of $17 \beta$-estradiol on progesterone production by highly differentiated porcine granulosa cells in vitro. II. Regulatory interactions of estradiol with luteinizing hormone and cyclic nucleotides. Endocrinology 109, 433-442.

Veldhuis, J.D., Klase, P.A., Strauss, J.F., III \& Hammond, J.M. (1982a) The role of estradiol as a biological amplifier of the actions of follicle-stimulating hormone: in vitro studies in swine granulosa cells. Endocrinology 111, 144-ISI.

Veldhuis, J.D., Klase, P.A., Strauss, J.F., III \& Hammond, J.M. (1982b) Facilitative interactions between estradiol and luteinizing hormone in the regulation of progesterone production by cultured swine granulosa cells: relation to cellular cholesterol metabolism. Endocrinology 111, 441-447.

Veldhuis, J.D., Klase, P. A. \& Demers, L.M. (1982c) Luteinizing hormone stimulates the production of prostacyclin by isolated ovarian cells in vitro. Prostaglandins 23, 319-327.

Veldhuis, J.D., Demers, L.M., Azimi, P., Juchter, D. \& Garmey, J. (1987a) Activation of protein kinase $C$ is coupled to PGF $_{23}$ synthesis in the ovary: studies in cultured swine granulosa cells. Molec. cell. Endocr. 49, 249-254.

Veldhuis, J.D., Nestler, J.E. \& Strauss, J.F., III (1987b) The insulin-like growth factor, IGF.I (somatomedin C), modulates low-density lipoprotein metabolism by swine granulosa cells. Endocrinology 121, 340-346.

Veldhuis, J.D., Azimi, P., Garmey, J. \& Juchter, D. (1988) Follicle-stimulating hormone regulates low density lipoprotein metabolism by swine granulosa cells. Endocrinology 123, 1660-1667.

Weiss, M. \& Eckstein, B. (1983) Periovulatory changes in steroid $C_{17.20}$-lyase activity in ovaries of immature rats treated with pregnant mares' serum gonadotropin. Endocrinology 114, 1912-1916.

Welsh, T.H., Jr, Jones, P.B.C., Ruiz de Galarreta, C.M., Fanjul, L.F. \& Hsueh, A.J.W. (1982) Androgen regulation of progestin biosynthetic enzymes in FSHtreated rat granulosa cells in vitro. Steroids $\mathbf{4 0}$, $691-700$. 